\title{
sciendo
}

DOI: $10.2478 /$ jolace-2021-0014

\section{Didactic and pedagogical dimensions of Igbo oral children's songs}

\author{
Onyebuchi Nwosu, Obinna Ibezim \& Ngozi G. Ugochukwu \\ Alex Ekwueme Federal University Ndufu-Alike, Nigeria \\ buchinwosu@yahoo.com
}

\begin{abstract}
There is a sharp decline in the performance of Igbo oral songs by children in recent times. Unlike in the days gone, children of nowadays rarely gather in groups in the evenings or during moonlight nights to play and perform some dramatic and musical renditions which are informal forms of education. Parents now encourage their children to watch home-movies and some channel programmes in the comfort of their homes; they encourage them to embark more on some in-door games while advancing security reasons as the basis for not allowing them to participate in various forms of open communal recreation. Such attitude deprives children of the essential moralistic and educational values expected to be imbibed from the rendition of native songs in playful groups. This paper which is based on a fieldwork carried out in 2018 in Umuawuchi, an Igbo community in Imo State Nigeria, investigates the instructional values of Igbo oral children's songs. Reiterating the moral-imparting attributes of Igbo children's songs, the paper applies Performance Theory to investigate the thematic standpoints of Igbo children's songs while gauging the extent to which they can be applied to impart and extrapolate on key moral values of the Igbo. The paper restates certain measures that can be activated to incorporate children's songs into mainstream educational and mass-communication media to avert the complete loss of such rich literary repertoires.
\end{abstract}

Key words: children's literature, folklore, oral songs, Igbo

\section{Introduction}

A song is a melodious tone, orally produced that often entertains as it also soothes and educates. According to Conesa and Rubio (2015, p. 86), "songs are a form of language that use tones and rhythm and they are also the media of universal language for everybody". This implies that whether one understands a language or not, one is somehow bound to appreciate the vocal tone and rhythm expressed in that language in form of song or music. Unlike other oral renditions, (chant and recitation) "the song is characterized by the highest degree of musicality.... In the songs, however, we reach the highest level of vocal manipulation, the singer exploits the high and low tones of speech at several levels to achieve an even higher degree of affecting melody" (Okpewho, 1992, p. 133). Among the Igbo of South-eastern Nigeria, $a b u$ is literally regarded as song and according to Chukwuma (1994, p. 34), "this is a representative term whose meaning is best caught by verse or poetry.... Igbo oral poetry is sung, recited or chanted.... Most Igbo songs are usually danced to." To her, song or $a b u$, best captures the genre regarded in Igbo literature as poetry though she acknowledges that the singing of most Igbo songs goes simultaneously with some kind of physical movement or display. Categorizing the Igbo poetic forms which she refers to as " $a b u$ ", Chukwuma (1994, p. 42) further identifies a type she calls "abu umuaka: children's songs." Explaining it, she says that "these songs include what in western usage are lullabies and rhymes. Mothers have a traditional stock of songs which they sing for their children and older children sing these for their own entertainment while at play." We would quickly add that in Igbo, children's songs are more than lullabies and rhymes. Citing Onwuka (1987, p. 30) Emejulu (1999, p. 3) identifies eight categories of Igbo children's songs: nursing songs or lullabies, tale songs, 
praise songs, school songs, teasing songs, and religious songs. A seventh category, the riddle or mental activity song... also added is topical songs' grouping..." Children's songs constitute an important aspect of Igbo oral poetry and as Sullivan (2018, p. 69) notes, "oral poetry whether handed down traditionally to deal with recurring situations or created and circulated in response to contemporary cultural stimuli, forms a very large part of younger children's folklore." In Igbo oral poetry, children's songs are learned as well as composed to cater for traditional and contemporary social exigencies. The major parts of these social situations that this essay is concerned with are the moral-imparting and educational angles of children's songs. This essay is structured into five segments, while the first which is an introduction foregrounds the discussion, the second segment discusses the concept of children's songs. The third section explains the methodology and the theoretical framework for the study. This is followed by an analysis of the didactic and pedagogical resources of Igbo oral children's songs after which is the concluding section.

\section{Igbo oral children's songs}

A song is a "piece of music performed by single voice, with or without instrumental accompaniment" (Britannica.com). It then means that a song can be an ordinary vocal rendition (speech) or that which is accompanied with sound of some musical instruments. As a product of the masterful manipulation of the vocal cord with other musical instruments to produce a mellifluous sound, Okpewho (1992, p. 134) asserts that "it is in areas of instrumental accompaniment and audience participation that the song demonstrates its superiority to the other modes of performance." This implies that singing (which produces songs) are usually accompanied with some musical instruments while the rendition is better carried out in a group (audience participation).

There are basically two types of songs as an entry in britannica.com illustrates:

In Western music, folk song is customarily distinguished from art song. Folk songs are usually sung unaccompanied or with accompaniment provided by a single instrument... They are usually learned by ear and are infrequently written down; hence they are susceptible to changes of notes and words through generations of oral transmission. Composers of most oral folk songs are unknown (Britannica.com).

Art songs as opposed to folk songs, from the above explanation, are vocal renditions which are accompanied or unaccompanied by instruments but are deliberately and conscientiously composed and rendered by an individual or group. Most times, they are written down making their wordings and rhythms not to change frequently while the composers are usually known. In this essay, our attention is more on folk songs which are mostly rendered in traditional societies as explained below:

In peasant society, singing is a form of personal and social expression, an inherent part of community life. The performers of vocal music are not professionals, though good voice and musical ability is recognised and in certain functions required (The Concise Garland Encyclopedia of Music, p. 581).

The assertion above is quite imperative because in most folk or "tradition-oriented societies" (Ebeogu, 1998, p. 1) singing can be carried out individually or in group. Singing is also a vital part of the life of the people. Acknowledging this, Ganyi and Inyabiri (2013, p. 64) assert that "song composition everywhere is considered an attribute of an individual artist or group. In most cases song composers are regarded as endowed or gifted persons artistically. Giftedness notwithstanding, the process of composition is not 
exactly the same in all parts of the universe as it is subject to several variables." These variables include the environment, the nature of the audience/listeners, their stage of development as well as their culture (Ganyi \& Inyabiri, 2013, p. 64).

Adults and children render songs in almost all societies as each of them constitute a distinctive 'folk group.' Sullivan (2018:67) describes a folk group as that which "operates on a very 'high context' level...things happen in the group that outsiders would not understand without explanation." Children's world is entirely distinct from that of the adults, though the adults were once children and children will grow to become the adults of tomorrow. Therefore, children's songs revolve around their world, and incorporate their desires, thoughts, likes, dislikes, aspirations, beliefs among others. An online entry of the American library of congress elaborately defines children's songs thus:

Children's songs may include songs that adults sing or teach to children, songs children pass along to each other, and songs children compose themselves. These distinctions are not always clear cut, however, as adults may teach children songs that the learned from other children in childhood, and children may pass along a songs learned from adults to other children (loc.gov).

Children's songs are peculiar kinds of oral poetic performances which are particularly performed by children or are performed for them. They are songs composed and performed by children or those composed and performed by an adult or an older child to children in order to entertain the children, rock and lull them to sleep or to educate them. Entertainment, which is the pleasure and appealing aspect of children's songs is a given, for there is usually that feeling of joy and happiness associated with the rendition of children's songs. There is also an instructional dimension where the songs are rendered to impart somebody of knowledge and understanding. This second motive is what we refer to as the didactic cum pedagogical imperatives of children's songs. It constitutes the crux of all discussions in this paper as we try to find out the moral dimensions and educational attributes of Igbo oral children's songs.

\section{Methodology and theoretical framework}

The children's songs or texts on which the discussions in this essay are based are collected from a fieldwork we carried out in November 24 2018, in Umuawuchi Community in Ihitte-Uboma Local government Area of Imo State Nigeria. ${ }^{1}$ In the course of the fieldwork, precisely on Sunday, November 24, having informed them and their parents a day before, we called together children of primary school age in a kindred, Umuebonu, to perform for us some Igbo songs they render during their moments of relief or pleasure at home and those they render during "Free-Play or Break period in school. We were shocked by the magnitude and depth of their renditions. Some of them acted the roles of teachers as they rendered some Igbo songs they performed during "Free-play' in schools. Free Play is a forty-minute teacher-guided period of play carried out in most primary schools in Nigeria. Surprisingly, the singing lasted for more than two hours. We recorded their renditions with a digital recorder and served them soft drinks and confectionaries in appreciation of their efforts and information. We later retrieved the Igbo songs from the recorder by transcribing them the way they were exactly rendered in our dialect of Igbo language. The songs were also translated into English to widen the scope of their understanding.

Having acquired the texts (children's songs), we meditated on the appropriate theoretical framework to deploy in their study and arrived at Performance Studies Theory. With this, we took the rendition by the children as a form of oral performance. At 
the core of the term "performance" is the word "perform", and according to Schechner (2002, p. 28), "in the arts, to perform is to put on a show, a play, a dance, a concert. In everyday life, 'to perform' is to show off, to go to extremes, to underline an action for those who are watching." It has to do with a display or manifestation of an action that is witnessed by other people or being. To be best understood, the show or display is deliberate and purposeful as it is based on well-organized thought aimed at displaying an expected act. Performance is therefore the manifestation of some acts by any individual or group. It is the intrinsic action that is displayed by an individual or group aware that they are not alone but are being watched. In the words of Goffman (1965, p. 17), a "performance may be defined as all the activity of a given participant on a given occasion which serves to influence in any way any of the other participants. Taking a particular participant and his performance as a basic point of reference, we may refer to those who contribute to the other performances as the audience, observers, or co-participants." So every performance has both the performer (s) and the audience who cross-communicate; that is why Dubois (2012, p. 205) quotes Bauman (1986, p. 3) to have seen it "as a mode of communication, a way of speaking, the essence of which resides in the assumption of responsibility to an audience for display of communicative skills, highlighting the way in which communication is carried out, about and beyond its referential content." Performance as conceived above relies on the ability of performers and their audience to interact and deduce meaning from the activity of each party. In that essence, performers put up actions that are capable of signalling some meanings to the audience who decode the information and most times exhibit some responses in reaction to the performance

Performance Studies involve the interpretation of the meanings that are in and around performances which put in a simple form are displays of purposeful actions. As Schechner (2002, p. 2) remarks, "performance studies starts where most limited-domain disciplines end. A performance studies scholar examines texts, architecture, visual arts, or any other item or artifact of art or culture not in themselves, but as players in ongoing relationships, that is, "as performances." Schechner (2002, pp. 1-2) further outlines the major ways in which Performance Studies operate by taking "actions or performance" seriously. From there we deduce the following: That Performance Studies focus on humanly exhibited actions and the perceptions and interpretations of those actions, that most performance studies scholars are performance aficionados or participants in various performances, that performance studies entails carrying out a fieldwork by a researcher who also does a critical analysis of the collected data based on his position as a 'participant observer' who has knowledge of what other people have done, and that the performance studies scholar takes a position after carefully studying the positions others have taken and is ready to stick to his position or review and revise it.

From the above, our decision to deploy Performance studies as the guiding framework for this study is hinged on the following reasons: The children's songs (the texts under scrutiny in this essay) are products of a fieldwork. They are produced in a moment of intense singing and dancing (a form of oral performance) by children. Despite that the gathering was pre-arranged, though on a very short notice, the children performed as if they have rehearsed their rendition for some time. At intervals, they nominated a lead singer; then they sang, danced and acted as the lead singer directed them. Also, the impromptu rendition at a point took the form of a typical oral performance session where apart from the researchers, other villagers gathered to watch the performance (audience), some parents offered some guide to the children while some sent for their children to come and join making the number of the children to increase as the event progressed. Thirdly, the children's songs' rendition episode has all the paraphernalia of a performance 
session: It has audience; performers, text of the songs which were rendered, music- vocal singing and clapping of hands in some instances, there are moments of digression and use of para-linguistic features like gestures, gesticulations, twitching of the face, shaking of the head etc. Convinced that the children's songs are oral artefacts produced during an oral performance, the best theory to apply in their study is Performance Studies. However, the study is not really directed towards ascertaining the strengths of children's songs as forms of oral performance per se, instead, it attempts to identify the moralcensoring/imparting nature of the songs as well as their ability to be effectively deployed as instructional media.

\section{Didactic and pedagogical dimensions of Igbo oral children's songs}

In one of his foremost studies on folklore, Bascom (1965, p. 294) affirms that "...folklore fulfils the important but often overlooked function of maintaining conformity to the accepted patterns of behaviour... Some forms of folklore are important as means of applying social pressure and exercising social control." By this, folklore which is also referred to as 'oral literature' (Finnegan, 1970, p. 25) is portrayed as having the ability to inculcate acceptable mode of behaviour on people while also helping to check or censure misbehaviours. This, points to the didactic functions of oral renditions, especially oral poetry and corroborating this, Mba and Mbah (2007, p. 150) posit that didactic "...poetry is the genius of poetic forms that is used to teach some moral philosophical systems, which offers instruction through the medium of verse or any branch of learning. It is mostly designed to instruct; it contains perspective precepts of people in spite of the fact that it may appear opinionated." The underlining fact from the above explanation is that didactic poetry deploys the facility of verse or poetry to teach moral lessons or advise and prescribe to people how to live their lives.

In the course of this study, the children's song below is identified to have some didactic effects as it offers some ontological explanations about the inimitable phenomenon of death. It has a soloist- chorus pattern and instils in children some philosophical precepts about death:

\begin{tabular}{|c|c|c|c|}
\hline Soloist: & Ọchicha ochacha & Soloist: & $\begin{array}{l}\text { Crocroach crocroach } \\
\text { No one should }\end{array}$ \\
\hline & Onye a rala mmanu ura & & $\begin{array}{l}\text { No one should } \\
\text { Lick overnight oil }\end{array}$ \\
\hline Chorus: & Kpango! & Chorus & Kpango! \\
\hline & Ochicha ochicha & Soloist & Crocroach crocroach \\
\hline Soloist: & Onye a rala mmanu ura & & No one should \\
\hline Chorus: & Kpango! & & Lick overnight oil \\
\hline Soloist: & $\begin{array}{l}\text { N'ihi na Ọchicha wawa anya } \\
\text { Okuko e buru ya O! }\end{array}$ & $\begin{array}{l}\text { Chorus } \\
\text { Soloist }\end{array}$ & Kpango! \\
\hline Chorus: & Kpango! & & $\begin{array}{l}\text { Boasts of its strength } \\
\text { A fowl will swallow it }\end{array}$ \\
\hline Soloist: & $\begin{array}{l}\text { Ọkuko wawa anya } \\
\text { Eqbe e buru ya }\end{array}$ & $\begin{array}{l}\text { Chorus } \\
\text { Soloist }\end{array}$ & $\begin{array}{l}\text { Kpango! } \\
\text { If a fowl boasts of its strength }\end{array}$ \\
\hline Chorus & Kpango! & & A kite will whisk it away \\
\hline Soloist & $\begin{array}{l}\text { Egbe wawa anya } \\
\text { Egbe e ghuo ya }\end{array}$ & $\begin{array}{l}\text { Chorus } \\
\text { Soloist }\end{array}$ & $\begin{array}{l}\text { Kpango! } \\
\text { If a kite boasts of its strength } \\
\text { A gun will kill it }\end{array}$ \\
\hline Chorus & Kpango! & Chorus & Kpango! \\
\hline Soloist & $\begin{array}{l}\text { Egbe wawa anya } \\
\text { A kujie ya n'ala }\end{array}$ & Soloist & $\begin{array}{l}\text { If a gun boast of its strength } \\
\text { It will be broken on the ground }\end{array}$ \\
\hline $\begin{array}{l}\text { Chorus } \\
\text { Soloist: }\end{array}$ & $\begin{array}{l}\text { Kpango } \\
\text { Ala wawa anya }\end{array}$ & $\begin{array}{l}\text { Chorus } \\
\text { Soloist }\end{array}$ & $\begin{array}{l}\text { Kpango } \\
\text { If the ground boasts of its strength } \\
\text { A little shit is dropped on it }\end{array}$ \\
\hline
\end{tabular}




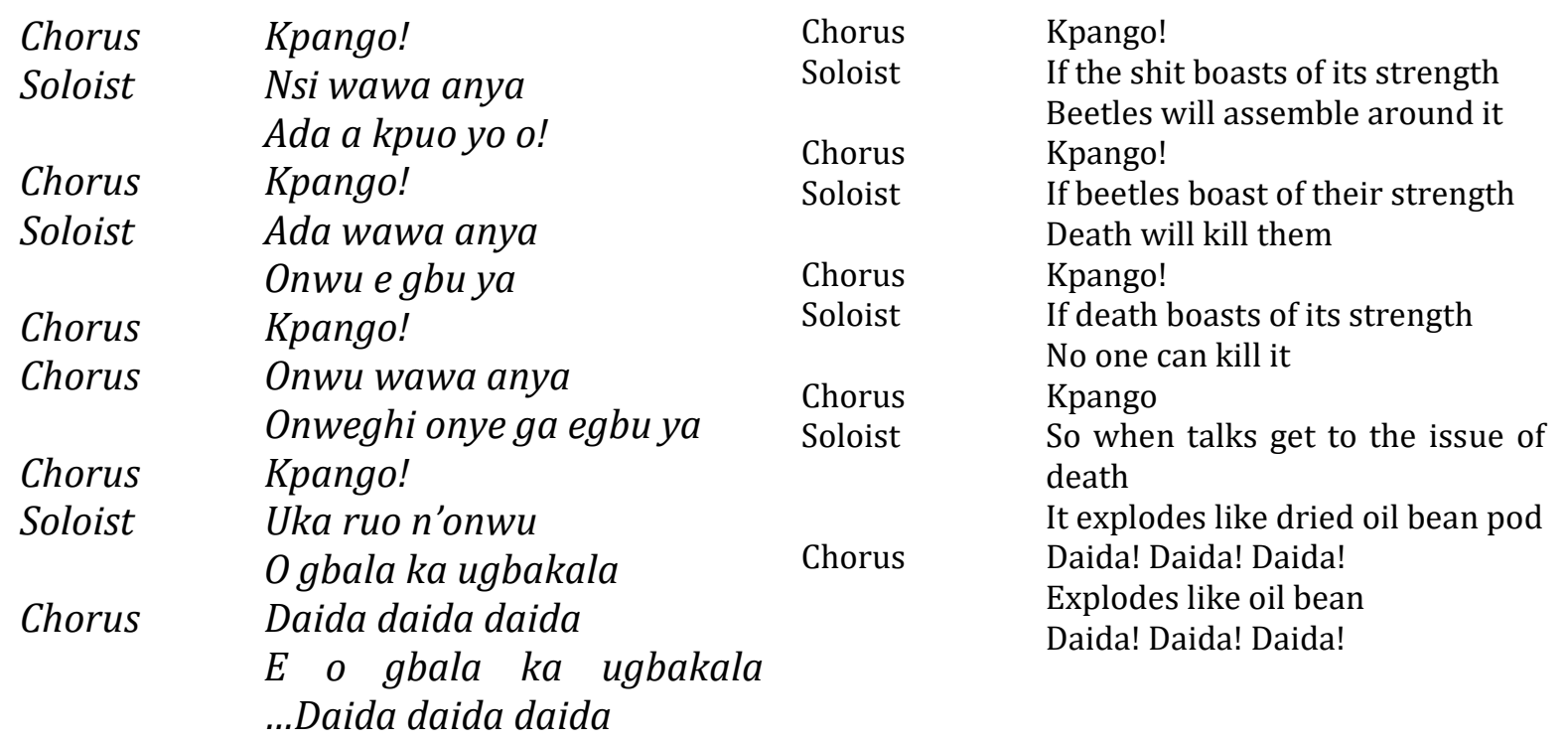

There is a steep-wise flow of thoughts in the song until it gets to the climax which is "when talks get to the issue of death." This gives the song a laudable effect as a veritable poetic piece. The song has a high philosophical undertone that amplifies the unconquerable nature of death. It highlights the weaknesses and vulnerability of all things except death. It teaches the supreme power of death and the fact that every creature or object on earth has something that is stronger than it or that which can destroy it but it is only death that has nothing that can withstand or annihilate it. In rendering the song, the children appointed a lead-singer or soloist who takes the main lines while others chorus "kpango!" which is the refrain. The song has a formulaic beginning, which is repeated twice for emphasis. The same pattern goes to the ending lines which reiterates the fact that when any issue gets to the point of death, it is difficult to handle as death has no rival. As they sing the last lines, the children march and patter their feet on the ground to attract the attention of listeners and inform them that therein reside the crux of the message in the song. They face each other, talking to one another, as if they are reminding themselves that death is so powerful. As the song is rendered, there is mimicry of the sound made by dry oil bean pod when it explodes after being heated by the sun to release the oil-bean seeds housed in it--“daida daida!" The idiophone-like refrain "kpango!" is a meaningless sound whose rhythm stirs the minds of the singers (children) and helps them to set the musical note for the song. On hearing the song as it was being rendered by children, we were perplexed that a children's song should have such rich philosophical thought; that which will make anyone meditate on the powerful and mysterious nature of death.

Next is another children's song that teaches the dangers of being ignorant or unintelligent which is symbolically represented in the song as being blind:

Oke ito kpuru ishi

Lee ka ha si agba oso

Ha gbakwuru otu nwanyi n'úbi ya

O were mma di nko gbubie ha odu

I hula ihe di otua n'elu uwa nke a?

Oke ito kpuru ishi.
Three blind rats

See how they are running

They ran to a woman working in her farm

She used a sharp machete and cut their tails

Have you seen anything like that in this world?

Three blind rats! 
The song which is both symbolical and allegorical, tells a simple story with animal and human characters. It tells the story of three blind rats that out of their blindness stray into a woman's farm, where she cuts off their tails. As it is rendered, the children dramatize it by mimicking the movements of the three rats and the woman who finally cuts off their tails. From the explanations offered by the children who performed the song, the meaning of the song has much to do with ignorance and its subsequent effects. The problem the three rats in the song have is their blindness and as the children explained, ignorance is like blindness. An ignorant fellow is like someone who is blind-folded; he can easily stray into the territory of his enemy who would simply cause some harm to him. Also, one who is ignorant is usually vulnerable to one vicissitude of life or the other. According to the children, the song is rendered to lampoon truants or anyone who is not paying serious attention to becoming educated or going to school. They warn the person that such recalcitrant act would make him become ignorant or 'blind' like the three rats and the person's life will be in great jeopardy. So whenever children sing the song, they indirectly advise themselves on the gains of being educated or gaining knowledge which will remove the veil of ignorance over their lives and make them to be enlightened so that they will not be groping about in the world like the three blind rats.

Another oral children's song we encountered during the study warns children on the dangers of not paying attention to their studies:

Soloist: O gara sụkụlu a maghi akwụkwo Chorus: Onye lebura ka ya mma!

Soloist: O gara sukulu a maghi akwụkwo Chorus: Onye lebura ka ya mma!
Soloist: One who goes to school but can't read or write Chorus: An ordinary labourer is better than him! Soloist: One who goes to school but isn't enlightened Chorus: An ordinary labourer is better than him!

This satirical song admonishes children to take their academic work seriously so that they can acquire knowledge and professional skills, if not, they will end up becoming unskilled labourers who do menial jobs. A labourer's work does not require any significant professional skill, so, the song is saying that a labourer is better in many forms than one who wasted his/her time going to school without acquiring much knowledge or learning a professional skill. The labourer did not waste his time going to school and no resources were wasted in training him or her. Also, children sing the song to caution anyone among them who in spite of going to school still behaves crudely and exhibits unrefined manners. Through rendering the song, they taunt the person and force him/her into a kind of personal recollection where the person will decide to exert some level of civility in his or her conducts. The thrust of the song is that the conduct and status of anyone who has gone to school should reflect some level of civility and enlightenment, if not, the time the person has spent in getting educated is a waste.

Away from education, another children's song we encountered, though rendered by children made up of both sexes, admonish young maidens on the danger of being overselective of suitors when they reach the age of marriage:

$\mathrm{Abu}$

Nwada O ga alu di n'ole? Nwada ga alu di n'Afo Nwada si mba ma chio! Nwada O ga alu di n'ole? Nwada ga alu di na Nkwo Nwada si mba ma chi o!
Aziza

Amangoringori Amangoringori Amangoringori Amangoringori Amangoringori Amangoringori 


$\begin{array}{ll}\text { Okweghi izu n'abo nke atọ } & \text { Amangoringori } \\ \text { Ha si Nwada di ime } & \text { Amangoringori } \\ \text { O kweghi izu n'abo nke ato } & \text { Amangoringori } \\ \text { Ha si Nwada a muọla } & \text { Amangoringori } \\ \text { Anyi gawa ile Nwada } & \text { Amangoringori } \\ \text { Anyi puọ n'ikpa ukwu } & \text { Amangoringori } \\ \text { Anyi puo n'ikpe nta } & \text { Amangoringori } \\ \text { Ndi na egbu opi egbuolo o } & \\ \text { Ole isi ya o? } & \text { Amangoringori } \\ \text { Ole odu ya o? } & \text { Amangoringori }\end{array}$

Song

When will Nwada marry?

Nwada will mary on Afo day

Nwada said no - not at all

When will nwada marry?

Nwada will marry on Nkwo day

Nwada said no - not at all

Not up to two weeks by the third

They said Nwada was pregnant

Not up to two weeks, by the third

We heard that Nwada has given birth

We went to se Nwada

We got to a big desert

We got to a small desert

People who have the flute have blown it

Where is the head?

Where is its tail?
Refrain

Amangoringori!

Amangoringori

Amangoringori

Amangoringori

Amangoringori

Amangorigori

Amangoringori

Amangoringori

Amangoringori

Amangoringori

Amangoringori

Amangoringori

Amangoringori

Amangoringori

Amangoringori

This is a typical children's tale song with a complete story of a girl named Nwada. Nwada is an Igbo generic name for any nubile marriageable young woman. The story in this song is complete to a large extent; Nwada who is fond of refusing suitors suddenly becomes pregnant and the characters in the story decided to pay her a visit. May be to enquire from her how she got pregnant without first getting married or to jeer at and taunt her. Their mission may even be to deal with her in accordance with the laws of the land for in Igbo land; teenage pregnancy or pregnancy begotten outside marriage is anathema especially for young unmarried girls. From the song, it is surprising that Nwada who has rejected the idea of marrying has suddenly become pregnant. The song makes jest of people like Nwada who reject marriage outright but go ahead to indulge in sex which is an activity ordained only for married people. According to the children, the song is usually adopted to disparage a girl who takes-in outside wedlock. In disparaging her, other young girls are cautioned to be wiser and not indulge is pre-marital sex. The two rhetorical questions at the end of the song: "Where is the head? and "Where is its tail?" are Igbo idiomatic expressions directed at both Nwada who said that she would not marry, but got pregnant outside marriage, and the people who on getting the shocking news of her pregnancy, went to see (jeer at) her. The Igbo idiomatic expression seems to be cautioning both Nwada and the people who had gone to jeer at her to be wary of their actions for while Nwada has not done well to reject many suitors only for her to become 
pregnant without being married, the people who journeyed the long way to only jeer at her have not done well too. Indirectly, the song cautions girls not to be too selective of suitors but if they must, they should also abstain completely from pre-marital sex.

Another didactic song discovered in the course of this study is a short legendary one that discourages children from having I-too-know or I-know- it-all disposition:

Agbim zowa baisikuru

A ma $m$ ihe $m$ na azo!

Zowa baisikuru

A ma $m$ ihe $m$ na azo!
Agbim move the bicycle

I know what I am marching

Pedal the bicycle

I know what I am pedaling!

As the song is intoned, the children are thrown into an intensive frenzy as they dramatize the actions in the song. The origin of the song is linked to a legendary event that took place in Umuawuchi community some years ago. One of the rich men in the community who does not know how to ride a bicycle went to Umuahia, the nearest city and bought a bicycle which was driven to the village square in a taxi he boarded. Then when the bicycle was brought down from the car, the man boasted and insisted that he would ride the bicycle home to complete the remaining part of the journey. As the first man to perform the feat of buying a bicycle in the community, many people gathered to witness the event. Some elders advised him to push the bicycle home, since he does not know how to ride it but he refused. Finally, Agbim climbed onto the bicycle, placed each of his feet on the corresponding pedal but as he made to ride the bicycle, he tumbled and landed on the ground sustaining so many injuries that kept him at home for over six months while the bicycle was kept in a corner in his house. Out of fear, he never learned to ride the bicycle nor rode it till he died. So whenever the song is intoned in the community it is meant to taunt anyone exhibiting the over-sabi- or overly intelligent act. For the children, the song warns them against being arrogant, instead it encourages them to learn from Agbim's experience to be humble and learn the skills expected of any venture before embarking on it. It informs them that it is dangerous to claim that one knows something or possesses a skill when in actual fact the person doesn't.

Another children's song imparts in them the feeling of compunction or remorseful repentance having committed a wrong.

$\begin{array}{ll}\text { A kuwaala m obo m ji ejere nne m ukpara } & \text { Ewooo! } \\ \text { A kuwaala m obo m ji ejere mme m ukpara } & \text { Ewooo! } \\ \text { Alekzanda nda nda, obo m nu okuwaala } & \\ \text { O di ka ukpara m e feliela } & \\ \text { Onye ga ejere nne m ukpara } \quad \text { Ewooo! } & \end{array}$

I've broken the gourd with which I go hunting for ukpara for my mother I'm sorry! I've broken the gourd with which I go hunting for ukpara for my mother I'm sorry! Alexander nda nda my gourd has broken

It seem all my ukpara have flown away

Who would go hunting ukpara for my mother I'm sorry!

In the years gone in Igbo land, the poorest of the poor who are not able to procure meat through hunting or buying it in the market resort to other forms of protein to enrich their food intake. Such measures include hunting for different species of grasshoppers in the 
forest. These species of insects hop and fly from one plant to another. Children from poor homes usually go in group for expeditions in the forest, to catch various species of grasshoppers. They usually go with a dried gourd with an opening at its top to safely collect and safeguard their spoil. The insects are captured live, and whenever any grasshopper is captured, it is put into the gourd and the mouth is covered with some leaves to prevent it from running away. However, woe betide any child whose gourd falls and breaks after the day's hunting toil as all the insects (he has captured) will run and fly away and the child would return to face the wrath of a disappointed parents who may be forced to cook the evening meal without any source of protein. The song above paints a scenario of such a situation; the child-speaker in the song has been quite unfortunate to experience the breaking of her hunting gourd and all her catch- the grasshoppers, have flown away. She is quite remorseful, wondering what would be the fate of her family and the punishment that would be meted out to her for her careless attitude which ultimately led to the breaking of the gourd. In singing the song, children learn to be remorseful after breaching a form of decorum or unwittingly performing an act that would cause a form of embarrassment or discomfort to their family. In rendering the song, the children wear sober and repentant countenance indicating that they are sympathizing with the unfortunate girl and also indicate that they have also grasped the message.

If the above children's songs give a kind of advice to the children on how they can live their lives or the things they should do or not do, there are others which have educational values as they teaches them about people and the universe. Such children's songs are pedagogical renditions which Mba and Mba (2007, p. 153) note as being related to didactic poetry but "present lessons on different topics and issues in the form of verse...." Though they are folk songs, they are deployed in the classrooms to teach certain things to children or help in explaining certain concepts to them. Mullen $(2017$, p. 1) in explaining them says that such pedagogical children's songs help in "supporting multiple domains of child development [especially in the] ...physical health and well-being, language and cognitive development, communication skills and general knowledge, social competence and emotional maturity." They generally aid mental and physical development of children. The first pedagogical children's song identified in this study uses the language instrument of code-mixing to teach children the four cardinal points which is an aspect of Geography:

O burụ na I lebe anya

N'ebe anyanwu si agba nwata

Iru gi bu Iist

Azu gi Westi

Aka ikpa gi bu Notu

Aka nri gi bu Sawutu

Otu a ka anyi si amata

Ebe anyi na eje!
Oh child, if you position your gaze

To the direction from which the sun rises

Your front is East

Your back is West

Your left hand is North

Your right hand is South

That's how we get the bearing

of where we are going!

Rendered during the fieldwork performance session, one of the children specifically informed the researchers that the song above is rendered mostly in nursery and early primary schools. Though the composer is unknown, she said that teachers utilize the song to introduce the children to the idea of identifying the four cardinal points. Though an Igbo oral song, there is a mixture of English words (which are lavishly Igbolized) with that of Igbo words (Iist, Westi, Notu, Sawutu). Composers of the song made use of morhpemic substitution; because there are no equivalent single words for the cardinal points in Igbo 
lexicon, except for explanatory phrases like (owuwa-anyanwu-east, odida-anyanwuwest, mgbago-ugwu-north, odida-ugwu-south), the English equivalents are Igbolized to impart same meaning. The song teaches children, aspects of Geography-the cardinal points which help in locating one's bearing and navigation. Using what the children are familiar with; that is the position of the sun, as it rises and sets, the song teaches them how to identify their bearing or the direction "of where they are going."

Other children's songs play vital roles in children's physical development as they constitute materials for games and exercises. Below is a typical example:

Gbasaa oku mbara

Eeee okụ mbarambara!
Form a circle

A big circle!

This is an Igbo translation of a popular English nursery rhyme that is adopted in most primary schools to help children exercise their body. It is usually the opening song during the time for "Free-Play" in most nursery and early primary schools during. Most times, the English and Igbo versions are rendered side by side indicating a kind of language acculturation and adaptation. As the song is sang, the children holding their hands together form a big circle jumping up and down to exercise their body. This is followed by another song that requires the children to dramatize the movement of 'small bird' while still maintaining their circular structure:

Nwannu nwannu nta
Turuzamzam turuzam!
Nwannu nwannu nta
Turuzamzam turuzam!
I no ebe ahu eme gini
Turuzamzam turuzam!
A no m ebe a aturi oka
Turuzamzam turuzam!
Gosinu m ka ịsi atu
Tuturiri tuturiri
Na ama nwoke
Na am nwayi

Nwannu nwannu nta

Turuzamzam turuzam!

Nwannu nwannu nta

Turuzamzam turuzam!

Turuzamzam turuzam!

A no $m$ ebe a aturi oka

Turuzamzam turuzam!

Gosinu m ka isi atu

Tuturiri tuturiri

Na am nwayi

\author{
Little bird, little bird \\ Turuzamzam turuzam! \\ Little bird, little bird \\ Turuzamzam turuzam! \\ What are you doing there? \\ Turuzamzam turuzam! \\ I am picking some maize \\ Show me how you are picking them \\ Tuturiri tuturiri \\ In a man's frontage \\ In a woman's frontage!
}

As the last part of the song is rendered, the children move zigzag as if they are some birds that are picking some grains. "Turuzamzam turuzam" is onomatopoeic of the quick skimpy movements made by birds while picking some grains. This helps the children to preen their muscles and exercise their bodies. The main reason the children render the song is not only to gain some knowledge from its lyrics, but holding each other's hands in their circular structure, they skimp and scamper around as the last two lines are rendered. Furthermore during moonlight nights, children gather together to play some games which are embedded in some songs. Below is an example of such song which the children performed during my fieldwork:

\begin{tabular}{|l|l|}
\hline Okereke okereke & Okereke Okereke \\
Dudu waai waaai & Dudu waai waai \\
Jiri abali chie eze & Who became a king overnight \\
Dudu waai waai & Dudu waai waai \\
\hline
\end{tabular}




\begin{tabular}{|l|l|}
\hline Okorafo Okoroafo & Okoroafor Okoroafor \\
Dudu wai wai & Dudu waai waai \\
Jiri abali chie eze & Who became a king overnight \\
Dudu wai wai & Dudu waai waai \\
Chara m chara $m$ & \\
Nga mmiri n'anwu gara ogu n'ikpa & Give me way, give me way \\
Ibe anyi o nakwa eru & Where the rain and the sun \\
Amakwa ebele ka ibe! & Go for a fight in the desert \\
Amakwa ebele ka ibe ya! & My people it's about to happen \\
& (For us to know) \\
& Among two rams which is the strongest \\
& Among two rams which is the strongest \\
\hline
\end{tabular}

This particular song is highly dramatized. Before the song is intoed, each of the children gets a short stick while squatting down and forming a circular structure. As this song is intoned, all the children who are participating in the dramatic performance that accompany it squat on the ground with each of them holding a short stick which he/she taps on the ground in tone with the rhythm of the chorus: "Dudu waai waai/Jiri abali chie eze/Dudu waai waai" When the singing gets to the line that reads "chara $\mathrm{m}$, chara $\mathrm{m}$ " "give way, give way) they draw a circle on the ground until the lead-singer sings "ibe anyi 0 nakwa eru" (my people, it's about to happen) and as the children sing the chorus, (amakwa ebele ka ibe!/Amakwa ebele ka ibe ya!) they exchange the stick by moving it to the right for the next person to pick. The dropping and picking of the stick follows the rhythm of the chorus and stops only when one of them fails to pick a stick kept for him; in that case he has failed the game and he is subsequently eliminated. He steps aside while the rest continue to determine among "the two rams which is the strongest" - that is to find out among the children who will be the winner. The good thing about the game is that the tempo of the song increases after every round of stick-taking and dropping and perhaps makes it easier for one to fall short of the game. It is usually played by children during break period in schools to widen their intellect. The song imparts the spirit of adroitness, resilience and sportsmanship on the children.

A similar song to the one above also imbues in the children the ability to be watchful readers of people's countenance, so that from one's countenance they can accurately guess their actions.

\begin{tabular}{|l|l|}
\hline Esem lee le, ese m lee le & My divination seed, my divination seed \\
Esem lee le, ese m lee le & My divination seed, my divination seed \\
Esem gara Amankwọ & My divination seed that went to Amankwọ \\
Esem gara Amankwọ & My divination seed that went to Amankwọ \\
Esem gara nga Okorafọ & My divination seed that went to the place Okoroafọ \\
Onye úkwụ oru & The one-legged man \\
Esem lee le, ese m lee le & My divination seed, my divination seed \\
Esem lee le, ese m lee le..... & My divination seed, my divination seed; \\
Onye ji egbe gbaa ngaaa o! & Whoever that has a gun should shoot it here \\
Tuwaaaaa! & Tuwaaaaal (aping the sound of a gun) \\
\hline
\end{tabular}


The above children's song is used to play the game of seed monitoring and holder's identification. To start the game, children sit one after the other in a straight line on the floor with their legs stretched out. Then their hands are put by the side of their laps in a way that they can collect something and pass it under their stretched legs without anyone seeing the object. Then the child at the beginning of the line is given a rubber seed (okwe) which is expected to be passed surreptitiously under its legs to others without any form of indication. So as the song is intoned, the children raise their legs and bring them down rhythmically and at the same time making way for the rubber seed to be secretly passed around them. A child among them is chosen to be on standby to monitor the movement of their legs. After sometime, the song is abruptly stopped and the child appointed to monitor the proceedings is expected to correctly guess who is in custody of the rubber seed. The child will point at anyone he feels has the rubber seed. Then the lead singer will now shout "Whoever that has the gun should shoot it here!" the person in custody of the seed will identify himself by shouting "Tuwaaaa!" If the person is exactly the one whom the person monitoring the movement has pointed at or guessed, they will swap their positions. The person who has guessed correctly the secret movement of the rubber seed will join those sitting down while the identified fellow will now be the one to monitor the movement as singing resumes. In singing the song and participating in the game, the children are trained to be sharp, observant and correctly pre-empt the action of others.

An important point to note is that the thoughts or meanings in some children's songs are sometime not complete as the interest is not often on the lyrics but on the melody and rhythm which provide music to carry out some physical and mental exercises. For instance, the lyrics of most lullabies or songs used to rock or lull children to sleep or tease them to stop crying, are not often made of full thoughts as the meaning sometimes are left hanging. That is why some people call lullabies, nonsense songs, but be it as it may, they serve some purposes. Below is an example:
A tufuo nwa n'ebe akwa
O ruo echi a muta ozo
If a crying baby is thrown away
Tomorrow another would be born.

It is as if giving birth to a child is such an easy venture or parents are so heartless that they are easily given to throwing away crying babies? No. The crux of this Igbo lullaby lies in its rhythm which goes with the rocking of a child while it is being held in both hands. Most times after singing the song and swinging the child both ways for some time, the child would stop crying or may often fall asleep. The same thing applies to this lullaby:

Onye muru nwa na ebe akwa?

Egbe muru nwa na ebe akwa

Weta uzuza weta ose

Weta amangororo ofe

Ka umunnunnu rachaa ya

Ka okpotiti kpogbuo ha

Onye onye egwu ozo
Who give birth to a crying child?

A kite gave birth to a crying child

Bring uzuza leaves

Bring pepper

Bring watery soup

So that little birds will lick it

So that the pain will kill them

Who, who...another song....

Some scholars are of the view that songs like lullabies which adults render to infants has a way of helping to build story-telling scaffold in them. "A child's experience with storytelling can begin with a simple rhyme shared with an adult.... Even if some children do not yet know the meaning of words, they have been playfully introduced to a short 
drama and building blocks of story: characters, plot, and setting" (Mullen 2017:47). In the lullaby above, emphasis is not on the meaning of the song but on the rhythm, that is why most of its lines are repeated so that it could lull a child to sleep or help make him to stop crying.

\section{Conclusion}

The study reveals that Igbo oral children's songs have moralistic and educational values as they play significant roles in imparting moral lessons and useful body of knowledge to children. As vital disseminators of knowledge of certain concepts and phenomenon like death, Igbo oral children's songs enlighten children on the need for them to pay serious attention to their studies which will help them fight against ignorance which is a terrible condition that can afflict anyone. Some Igbo oral children's songs satirize some youthful exuberance like truancy in school or anti-social behaviours like having an I-don't-care attitude or I-know-it-all disposition. They portray the dangers of having any of these undesirable traits and help to inculcate in children, some modest behaviours like being repentant and remorseful after in-deliberately committing a blunder or mistake that can jeopardize the wellbeing of their whole family or community. Furthermore, the study established that Igbo oral children's songs are utilized as recreational instruments with which children carry out some games and exercises that promote their mental and physical development. But most important, through the songs, children are taught some rudimentary topics like locating their direction and telling a short interesting story.

\section{Note}

1. We acknowledge the following children (Ikeneri Chikadibia, Ikeneri Chioma, Ikeneri Chiadi, Ogoke Chiehiura, Okoro, Chimuanya, pupils of Central School Uboma and Adaku Njoku, Ezenwa Ikegwu, Ebubechi Okeke, Ezinma Egeruo, pupils of Community School Umuawuchi) whose performance on November 24 2018, at one of the the Researcher's residence in Umuebonu Umuawuchi by $5: 30 \mathrm{pm}$, produced the songs which are used as texts in this study:

\section{References}

Bascom, W. (1965) "Four Functions of Folklore" The Study of Folklore Alan Dundes (ed.) New York: Prentice Hall pp.279-298.

"Children's Songs" https://www.oc.gov/songs-of-america/articles-and-essays/musicalstyles/traditional-and-ethnic/children-song/ [Accessed May 1 2020]

Chukwuma, H. (1194) Igbo Oral Literature: Theory and Tradition Enugu: Belpot Publishers.

Conesa, I. M. G. and Rubio, A. D J. (2015) “The Use of Rhymes and Songs in the Teaching of English in Primary Education" Docenciae Investigacion 25 (2): p. 83-101.

Dubois, T. A. (2012) "Oral Poetics: The Linguistics and Stylistics of Orality" Medieval Oral Literature Karl Reichl (ed.) pp.203-224.

https://doi.org/10.1515/9783110241129

Ebeogu, A. (1998) The African Folk and the Arts" Issues in Humanities and Social Sciences Afam Ebeogu \& Uzoma Nwokochah (eds.) Okigwe: Fasmen, pp. 1-25.

Emjulu, O. (1999) Children's Folklore and Literature in Nigeria: Uses, Benefits and Classifications" Review of Arts and Social Sciences 1 (1): October, p. 1-11.

Finnegan, R. (1970) Oral Literature in Africa Nairobi: OUP 
Ganyi, F. M. and Inyabiri, I. T. (2013) "Artistic and Creative Paradigms of Oral Narrative Performances: The Relavance of the Bakor Song Composer to his Contemporary Milieu" IORS Journal of Humanities and Social Sciences 13. Jul-Aug, pp. 65-73. Goffman, E. (1959) The Presentation of Self in Everyday Life New York: Doubleday. Sullivan, C. W. III (2018) "Children Oral Literature: Identify and Obscenity" Children Folklore Review 31.pp. 67-77. (Accessed April 28, 2020)

https://scholarworks.iu.edu/journals/index/php/cfr/article/view/205098/30972 Mbah B. M. and Mbah, E. E. (2007) Azuonye: Lectures on Igbo Literature and Stylistics Nsukka: University of Nsukka Press.

Mullen, G. (2017) "More thean Words: Using Nursery Rhymes and Songs to Support Domains of Child Development" Journal of Childhood Studies 42(2) pp. 42-53.

Opkewho, I. (1992) African Oral Literature: Background, Character and Continuity Bloomington \& Indianapolis: Indiana University Press.

Schechner, R. (2013) Performance Studies: An Introduction (3 ${ }^{\text {rd }}$ Edition) London \& New York: Routledge.

"Song" brittanica.com https://www.britannica.com/art/song [Accessed April 28, 2020] "Song" (2008) The Concise Garland Encyclopedia of World Music 1 New York: Routledge "Song" https://www.loc.gov/collection/songs-of-america/articles-and-essays/childrensong) [Accessed April 28, 2020]

\section{Contacts}

Onyebuchi Nwosu, Obinna Ibezim \& Ngozi G. Ugochukwu

Department of English and Literary Studies, Alex Ekwueme Federal University Ndufu-Alike

P. M. B. 1010

Abakaliki, Ebonyi State

Nigeria

buchinwosu@yahoo.com 